\title{
Patch Antenna based on a Photovoltaic Cell with a Dual resonance Frequency
}

\author{
Chokri Baccouch $^{1^{*}}$, Dhaou Bouchouicha ${ }^{1}$, Hedi Sakli ${ }^{1}$ and Taoufik Aguili ${ }^{1}$ \\ ${ }^{1}$ National Engineering School of Tunis, Tunis El Manar University, B.P. 37, Le Belvédère, 1002 SYS'COM Laboratory, \\ Tunis, Tunisia. \\ *corresponding author, E-mail: chokri.baccouch13egmail.com
}

\begin{abstract}
In the present work, photovoltaic solar cells are used in patch antenna structures. The radiating patch element of a patch antenna was replaced by a solar cell. Direct Current (DC) generation remained the original feature of the solar cell, but additionally it was now able to receive and transmit electromagnetic waves. Here, we used a new patch antenna structure based on a photovoltaic solar cell. It was then used to collect photo-generated current as well as Radio Frequency (RF) transmission. A mathematical model which would serve the minimization of power losses of the cell and therefore the improvement in the conversion efficiency was studied. A simulation allowed analyzing the performance of the antenna, with a silicon material, and testing its parameters such as the reflection coefficient (S11), gain, directivity and radiated power. The performance analysis of the solar cell patch antenna was conducted using Advanced Design System (ADS) software. Simulation results for this antenna showed a dual resonance frequency of $5.77 \mathrm{GHz}$ and of $6.18 \mathrm{GHz}$ with an effective return loss of $-38.22 \mathrm{~dB}$ and a gain of $1.59 \mathrm{dBi}$.
\end{abstract}

\section{Keywords:}

Patch Antenna, photovoltaic cell, optimization of the collection grid, optical and electrical losses, and electric power collected.

\section{Introduction}

Solar powered communication systems have received considerable attention due to their ability to operate without the necessity of being connected to an electricity grid. This has become a significant challenge when it comes to powering communication systems in remote places where the electricity grid is not available. In order to address this challenge, the use of photovoltaics in communication systems has recently been the subject of much research [1]. The photovoltaic systems of power generation when combined with communication systems can provide compact and reliable autonomous communication systems, which can be used for many applications. Solar energy has become an attractive alternative for powering autonomous communication systems. Many communication systems, such as standalone systems like environmental monitoring system, vehicular communication and satellite systems [2] require electric energy for their operation and use.
At present the photovoltaic generator and the antenna are two separate devices. They compete for the available space on mobile and stand alone systems which are generally limited in size. Furthermore they may be bulky and expensive and they limit the capabilities of product designs. The integration of photovoltaic solar cells with microwave antennas in a single multifunctional device potentially gives a wide range of advantages in terms of volume, weight, smart appearance and electrical performance to many applications when compared with a simple juxtaposition of antennas and solar cells [3- 7]. Additionally, it can reduce the marginal cost of renewable energy and thus improve its economic viability. New product designs and cost reduction become possible [8] and [9].Our contribution consists in combining the two devices into one (Fig.1) to overcome all the above disadvantages.

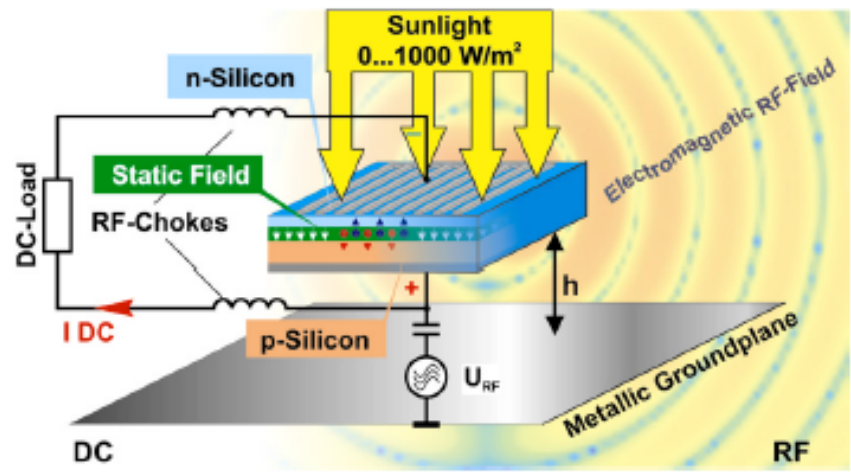

Figure 1. Basic principle of solar cell antennas

The solar cell whose backside contact was excited with a Radio Frequency (RF) signal was placed above a conducting ground plane. A decoupling network separated the RF from the DC current. The proposed Solar Planar Antenna consists in an appliance for the conversion of solar radiation energy into electric energy with at least one solar cell. The electrically conductive contacts of the solar cell were used as an antenna for the emission and reception of electromagnetic waves simultaneously.

The basic principle of the planar solar cell patch antenna is depicted in Fig. 1. In this exemplary case a galvanic coupling of the RF signal is shown. However other coupling methods (e.g. aperture coupling) are also possible. Since the 
solar cell has a DC circuit, the direct current path must be decoupled from the RF signal path in such a way that the DC load has no influence on the RF properties of the antenna. The decoupling can be realized by means of concentrated reactive elements and distributed elements, respectively.

The figure below returns to propose an integrated circuit that combines a solar cell and a patch antenna in a single device can at the same time to collect direct current, transmit and receive RF signals

Solar cell equivalent circuit is specially simulated in electronic work bench for measuring power (P), current (I) and voltage (V). Microstrip antenna equivalent circuit is separately simulated and the same output is measured. Finally both microstrip and solar cell circuits are combined and output is measured. While comparing both outputs, combination of microstrip and solar cell equivalent circuit produces high voltage $(\mathrm{V})$, current $(\mathrm{I})$ and power $(\mathrm{P})$. The simulation of SOLAN in Electronics work bench provides the following values of "current (I) $=872.8 \mathrm{~mA}$ Voltage $(\mathrm{V})$ $=8.728 \mathrm{mV}$ and Power $(\mathrm{P})=7.6177984 \mathrm{~mW}$ " were measured as shown in "Figure 2".

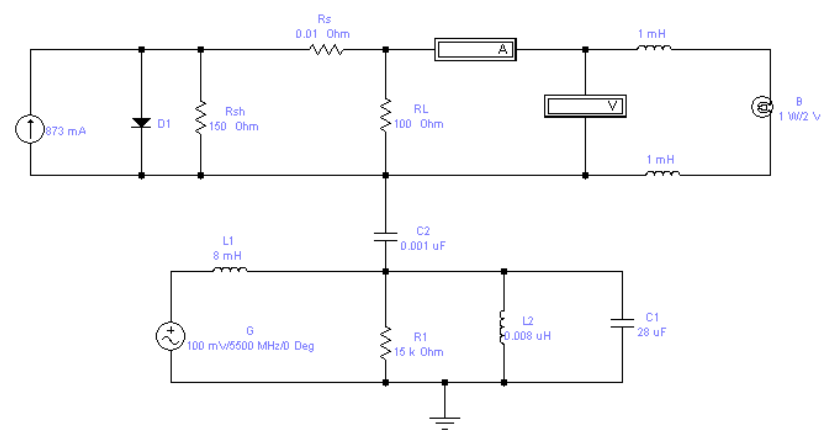

Figure2.Combined equivalent circuit of solar cell and microstrip antenna

\section{Approach and Optimization of geometry of patch antenna}

\section{A. Approach}

A solar cell or a photovoltaic cell is a device that converts photons from the sun radiation into electricity. The development of the thin amorphous silicon on polymer substrate solar cell technology made it possible to easily cut and fit the solar cells to various shapes, such as slot antennas, leading to optimized use of the available area, without affecting the radiating characteristics of the antenna [1]. The poly-Si solar cell consists of two metal contacts, a front grid (negative DC terminal) and a solid bottom (positive DC terminal) together with a silicon layer in between. Figure 3 shows the structure of a Solar Cell



Figure3. Structure of a Solar Cell

Our contribution of a patch antenna based on a photovoltaic cell was deduced from structure of the photovoltaic cell and that of a simple patch antenna. Structure of a simple patch antenna [10-11] is given by Figure 4

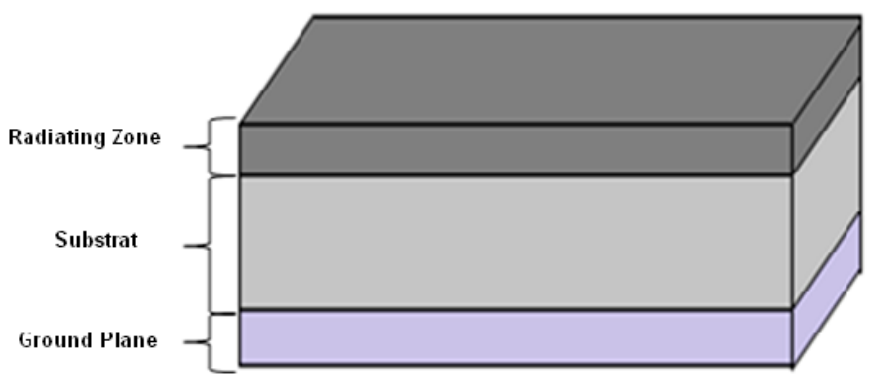

Figure 4. Structure of a simple Patch Antenna

The patch antenna structure proposed is given by the following figure (Figure.5)

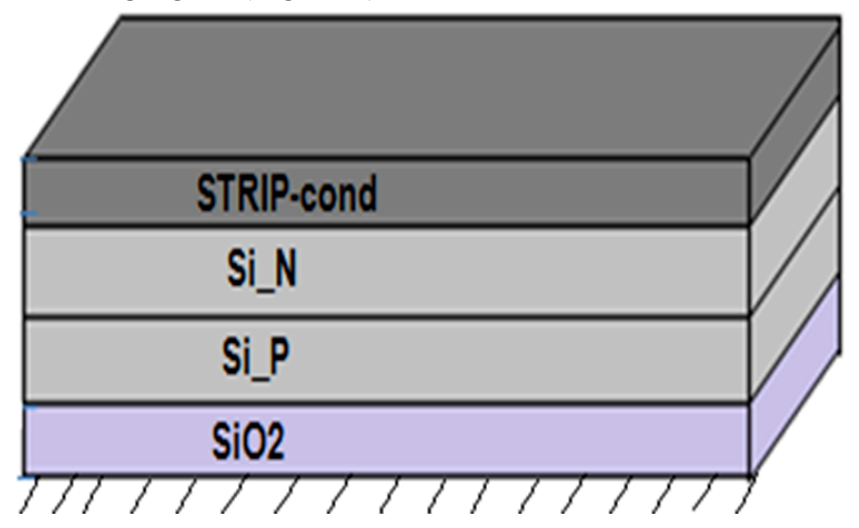

Figure5. Structure of a Patch Antenna based on a Solar Cell

From an RF point of view, attention should be given to the bottom metal contact of the cell, which is homogeneous in structure so that the cell can be used as a suspended RF stacked parasitic patch element in addition to its photovoltaic function (DC power generation). This was used to power the communication system in which the proposed solar antenna can be built. A significant challenge that needed to be addressed here was the effect of the DC 
copper wires at the cell terminals on minimizing the performance of RF antenna.

In this case we propose a hybrid autonomous wireless system "Solar Cell Antenna". Solar Cell antenna in our contribution combines both optical and radio-frequency antenna functions. As shown in Fig.6, the antenna transforms light into electricity via a photovoltaic cell to power all the active circuits in the system. It delivers electricity, through its power management interface, to the sensors (if required) and the radio transceiver. The excess energy is stored to ensure continuous operation of the wireless system when there is insufficient sunlight. The radio circuit transmits or receives data via the Photovoltaic antenna, which then acts as the radio antenna.



Figure6. Hybrid Autonomous wireless system using the photovoltaic antenna (Solar Cell Antenna)

Before, conventional wireless systems use a separate antenna and power source (Fig. 7). A battery provides a limited source of energy and has a limited lifetime, lasting from a few minutes to some years, and requires maintenance. The antenna is placed either inside the package or externally. The photovoltaic antenna eliminates an extra component in the system to achieve a higher integration.

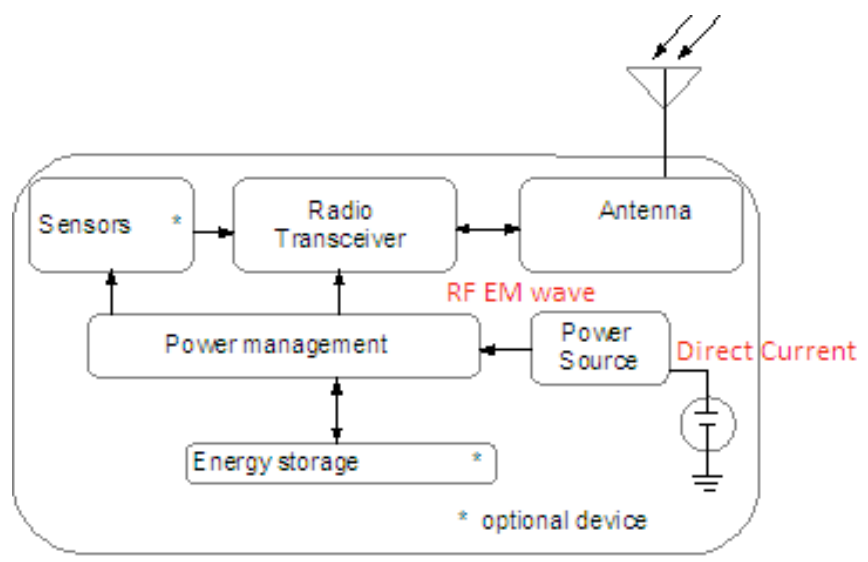

Figure6. Conventional wireless system block diagram.

The photovoltaic antenna has a smart design, which is optimized to receive maximum light and radiate or receive radio-frequency signals. The antenna uses a photovoltaic technology optimized for our application. It is possible to use semiconductor technologies, such as crystalline silicon, gallium arsenide, thin films, organic or dye sensitized solar cells.

\section{B. Optimization of geometry of patch antenna}

In its most basic form, a patch antenna consists in a radiating patch on one side of a dielectric substrate (in this case the a-Si), which has a ground plane on the other side (Fig 1). The patch is generally made of a conducting material such as copper or gold and can take any possible shape. The radiating patch and the feed lines are usually photo etched on the dielectric substrate. The hybrid structure was dedicated at a time to the energy recovery and the RF transmission. This structure was made of a photovoltaic cell in which the front grid was designed to have a miniature antenna suited to the band transmission and to minimize the power loss of the cell dedicated to energy conversion. The received electrical energy was used to operate the complete system.

As a first step of this work, we studied the optimization of the grid collection in the front face of a Solar Cell. Then we focused on the width of the metallic lines and their height which were chosen so that the losses (losses due to horizontal power in the transmitter, conduction losses in the metallic fingers, losses due to shading created by the grid ) of power produced by the voltage drop were minimal. There are three sources of losses due to the resistance series: resistance of the emissive layer, resistance of the grid and resistance of the contact metal/semi-conductor. The shading of the grid also contributes to the loss of power. The various contributions of resistance of a photovoltaic cell are shown in figure 8 [12].

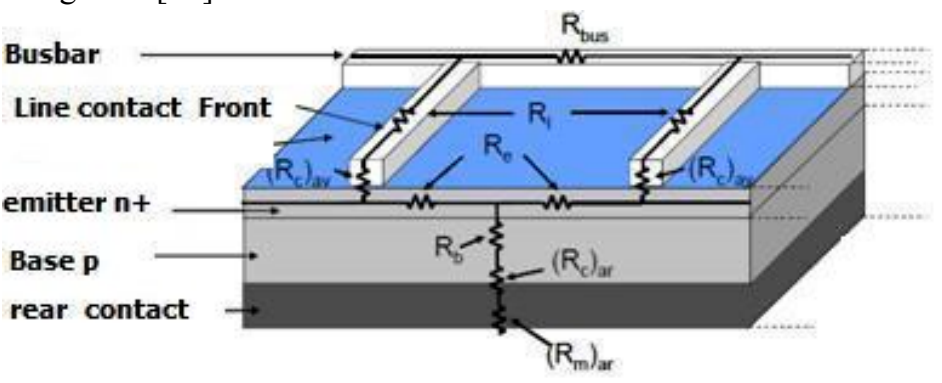

Figure8. Schematic representation of the different contributions of resistances of a Solar Cell

The linear grid structure was the simplest and represented the basis of calculation of the most complicated structures. The optimization of the geometry of the front side of the 
grid of the photovoltaic cell requires a detailed analysis of the optical and electrical losses caused by this grid. The total loss of a photovoltaic cell comprising a collector (busbars) and $\mathrm{n}$ fingers is given by [12-10]:

$$
P_{t}=P_{e}+P_{\text {gav }}+P_{b u s a v}+P_{c a v}+P_{b}+P_{F}
$$

with

$P_{e}:$ Power dissipated in the transmitter

$P_{g a v}:$ Power dissipated in the front grid

$P_{\text {busav }}:$ Power dissipated in the front bus

$P_{c a v}:$ Power dissipated in the front contact

$P_{b}:$ Power dissipated in the base

$P_{F}:$ Loss related to the shade rate.

Our goal was to reduce the total power loss. Therefore, we maximized the collected electric power for a finger width $w$ of the grid.

The rear face was entirely metalized making the associated resistance insignificant compared to other elements (transmitter, front grid...). In a solar cell, ohmic losses are associated with the current flow through the resistance of the metallic grid, the metal-semi-conductor, the substrate resistance and the transmitter region.

All losses dissipated equations are given in [20]

The power dissipated in the transmitter is given by

$$
P_{e}=J^{2} R_{e} L^{4}
$$

with

$$
\begin{gathered}
R_{e}=\frac{R_{s e} d^{2}}{12 L^{2}} \\
R_{s e}=\frac{\rho_{e}}{e}
\end{gathered}
$$

$R_{e}:$ Transmitter resistance $(\Omega)$.

$R_{s e}:$ Transmitter layer resistance $(\Omega / \mathrm{W})$.

$d$ : Distance between two fingers.

$L$ : Side of the square cell.

$J$ : Surface density of the current.

$e:$ Thickness of the transmitter.

$\rho_{e}:$ Transmitter resistivity $(\Omega . c m)$.

The power dissipated in the base is given by

$$
P_{b}=J^{2} R_{b} L^{4}
$$

with

$$
R_{b}=\frac{\rho_{b} w_{b}}{L^{2}}
$$

$R_{b}:$ Resistance of the base $(\Omega)$.

$\rho_{b}$ : Base resistivity $(\Omega . \mathrm{cm})$.

$w_{b}$ : Thickness of the base $(\mathrm{cm})$.

The power dissipated in the front side of the grid is given by

$$
P_{g a v}=J^{2} R_{g a v} L^{4}
$$

with

$$
\begin{aligned}
R_{\text {gav }} & =\frac{d}{48} \frac{R_{m}}{w} \\
R_{m} & =\frac{\rho_{m}}{h}
\end{aligned}
$$

$R_{g a v}:$ Resistance of the front $\operatorname{grid}(\Omega)$.

$R_{m}:$ Resistance of the metal $(\Omega)$.

$\rho_{m}:$ Metal resistivity $(\Omega . c m)$.

$w$ : Finger width $(\mathrm{cm})$.

$h:$ Metal thickness $(\mathrm{cm})$

The power dissipated in the busbars is

$$
P_{\text {bus }}=J^{2} R_{\text {bus }} L^{4}
$$

with

$$
\begin{gathered}
R_{b u s}=\frac{r_{b u s} d^{2}}{12 L w_{b u s}}\left(\frac{L^{2}}{2 m^{2} d^{2}}+3 \frac{L}{2 m d}+1\right) \\
r_{b u s}=\frac{\rho_{m}}{h_{b u s}}
\end{gathered}
$$

$R_{b u s}:$ Resistance of the collecting line (busbar) $(\Omega)$.

$w_{\text {bus }}$ : Width of busbar.

$m$ : Number of weld points on the current-collecting lines.

The power dissipated in the contact resistance is

$$
P_{\text {cav }}=J^{2} R_{\text {cav }} L^{4}
$$

with

$$
\begin{aligned}
R_{c a v} & =\frac{d}{2 L^{2}} L_{T} R_{s e} \operatorname{coth}\left(\frac{w}{2 L_{T}}\right) \\
L_{T} & =\sqrt{\frac{\rho_{c}}{R_{s e}}}
\end{aligned}
$$


$R_{c a v}:$ Resistance of front contact $(\Omega)$.

$L_{T}$ : Current density transfer length $(\mathrm{cm})$.

$\rho_{c}:$ contact resistivity front $\operatorname{side}\left(\Omega . \mathrm{cm}^{2}\right)$.

Losses out of shadow effect (or optical losses) are caused by the presence of metal on the front face of the solar cell which prevents light from penetrating. We define the overlap rate $\mathrm{F}$, also called the rate of shade, as the ratio between the top surface of the metal grid and the total surface of the cell [7].

$$
F=\frac{S_{r a v}}{L^{2}}=\left(w+\frac{2 w_{b u s}(d-w)}{L}\right) \cdot \frac{1}{d}
$$

It is clear that the hidden area is proportional to the distance between the fingers of the grid. The closer they are, the larger the surface of the metal grid is. Therefore, the surface exposed to the light weakens.

The power dissipated due to optical losses is

$$
P_{F}=F \cdot I_{m} \cdot V_{m}
$$

with

$I_{m}$ : The current supplied by the cell intensity.

$V_{m}$ : The voltage supplied by the cell.

The power collected by the cell is therefore

$$
P_{c o l}=P_{e c l}-P_{t}
$$

with

$P_{e c l}:$ power cell lighting.

$P_{t}$ : Total power dissipated due to resistive losses and shadow levels.

\section{Simulation results and discussions}

In addition to maximizing the absorption of radiation and minimizing the power losses, the final condition required to design a high performance solar cell was to minimize its parasitic resistive losses. From an optical point of view, the coverage rate or the shade rate must be low because the surface hidden by metallization is inactive. Therefore, there is a compromise between these two conditions, which tend to improve the energy conversion efficiency.

The base substrates used are generally in multicrystalline silicon. Useful parameters for the calculation of the various resistive and optical inputs from the standard serigraphic cell in the front face are given in Table I. The rear face of the cell was assumed to be a solid plate metalized with aluminum deposited by serigraphy.

\begin{tabular}{|c|c|c|}
\hline symbol & description & values \\
\hline $\mathrm{L}$ & $\begin{array}{l}\text { side of the } \\
\text { square cell }\end{array}$ & $12.5 \mathrm{~cm}$ \\
\hline d & $\begin{array}{c}\text { distance } \\
\text { between two } \\
\text { fingers }\end{array}$ & $0.25 \mathrm{~cm}$ \\
\hline $\mathrm{J}$ & $\begin{array}{l}\text { surface density } \\
\text { of the current }\end{array}$ & $0.03{\mathrm{~A} . \mathrm{cm}^{-2}}^{-2}$ \\
\hline $\mathrm{R}_{\mathrm{se}}$ & $\begin{array}{c}\text { transmitter } \\
\text { layer resistance }\end{array}$ & $40 \Omega / \square$ \\
\hline$\rho_{b}$ & base resistivity & $0.6 \Omega . \mathrm{cm}$ \\
\hline $\mathrm{w}_{\mathrm{b}}$ & $\begin{array}{l}\text { thickness of the } \\
\text { base }\end{array}$ & $2.10^{-2} \mathrm{~cm}$ \\
\hline $\begin{array}{c}\rho_{\mathrm{m}} \\
\mathrm{h}\end{array}$ & $\begin{array}{l}\text { metal resistivity } \\
\text { metal thickness }\end{array}$ & $\begin{array}{c}3.910^{-6} \Omega . \mathrm{cm} \\
1.510^{-3} \mathrm{~cm}\end{array}$ \\
\hline $\begin{array}{c}\mathrm{W}_{\text {bus }} \\
\mathrm{m}\end{array}$ & $\begin{array}{l}\text { Width of busbar } \\
\text { number of weld } \\
\text { points on the } \\
\text { current- } \\
\text { collecting lines }\end{array}$ & $\begin{array}{c}0.2 \mathrm{~cm} \\
10\end{array}$ \\
\hline$\rho_{\mathrm{c}}$ & $\begin{array}{l}\text { contact } \\
\text { resistivity front } \\
\text { side }\end{array}$ & $10^{-3} \Omega \mathrm{cm}^{2}$ \\
\hline $\mathrm{Vm}$ & $\begin{array}{c}\text { the voltage } \\
\text { supplied by the } \\
\text { cell }\end{array}$ & 0.5 \\
\hline
\end{tabular}

Table 1 Parameters used for the simulation of the calculation of the total losses of the photovoltaic cell on the front face.
Figure 9 shows the variation of power according to the width $\mathrm{w}$ of a finger. The maximum received power was $21 \mathrm{~W}$, for a lighting power of $P_{e c l}=1300 \mathrm{~W} / \mathrm{m}^{2}$ which corresponds to a width of a finger equal to $60 \mu \mathrm{m}$. This value of the finger width was useful for the antenna patch conception on silicon dedicated to $\mathrm{RF}$ transmission.

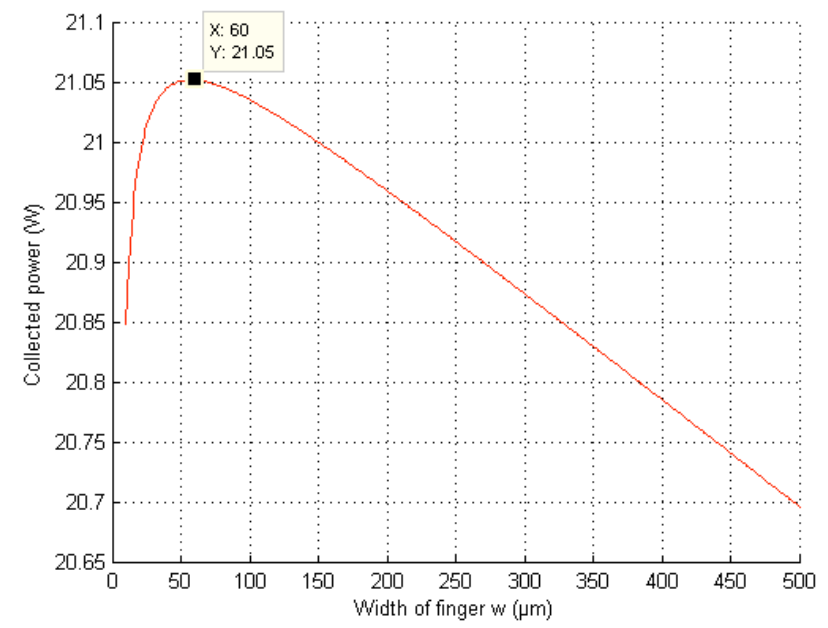

Figure9. Collected power according to finger width

The optimization of the front face of the collection grid requires the right choice of the geometry of the grid and its manufacturing material. 
We opted for a compromise between the optical losses and conduction losses to derive the geometrical dimensions of the optimized collection grid which would give the maximum cell productivity.

To test the parameters of the proposed patch antenna, we proposed a model (Figure 10) which was simulated using the ADS software, which was also used to model and simulate the microstrip patch antenna. This software has been widely used in the design of RF/wireless antenna, waveguide designs and filters. It can be used to determine and plot the reflection parameters, Voltage Standing Wave Ratio (VSWR), Impedance as well as the radiation patterns.

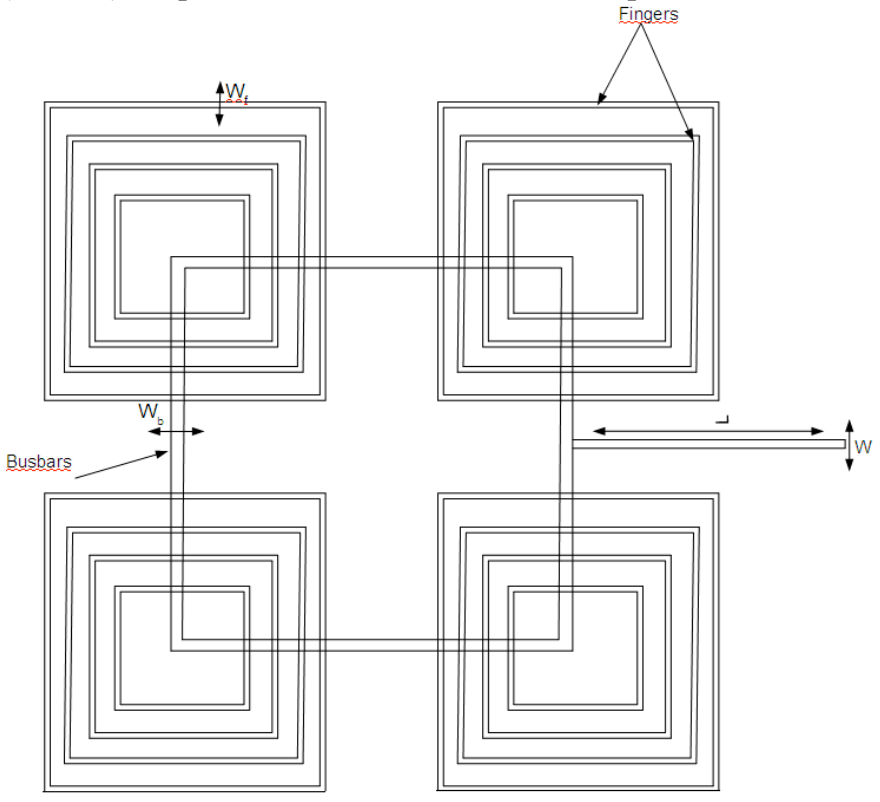

Figure10. Patch antenna proposed

$\mathrm{W}_{\mathrm{b}}=0.5 \mathrm{~mm}, \mathrm{~W}_{\mathrm{f}}=60 \mu \mathrm{m}, \mathrm{L}=9.1 \mathrm{~mm}, \mathrm{~W}=0.235 \mathrm{~mm}$

The designed structure was a printed antenna on a substrate compound of different layers of silicon, a layer of $\mathrm{n}$ junction $0.5 \mu \mathrm{m}$ thick and relative permittivity of $\varepsilon_{r 1}=11.9$, a second layer below P Junction, $300 \mu \mathrm{m}$ thick and $\varepsilon_{r 2}=11.8$ and a third layer, $\mathrm{SiO}_{2}$ having a thickness of $1.5 \mathrm{~mm}$ and $\varepsilon_{r 3}=3.9$, between the layer of connecting point $\mathrm{P}$ and the ground plane.

This antenna was excited by a microstrip line of $0.235 \mathrm{~mm}$ in width and of characteristic impedance equal to $50 \Omega$.

A simulation result of S11parameter was presented in Figure11. There is good agreement between the two. An antenna should be perfect radiator, rather than perfect absorber. The amount of radiated power returned back through the port can be calculated for finding return loss at that resonating frequency. For the resonant frequencies the return loss should be less than $-10 \mathrm{~dB}$ i.e. $\mathrm{S} 11<-10 \mathrm{~dB}$. Simulation results show that the designed antenna can be used as a frequency antenna with an effective return loss of $31.86 \mathrm{~dB}$ at $5.77 \mathrm{GHz}$ and $-38.22 \mathrm{~dB}$ at $6.18 \mathrm{GHz}$. The measured S11 and gain characteristics with the adequate solar performance confirm the efficiency of the proposed solar patch antenna.

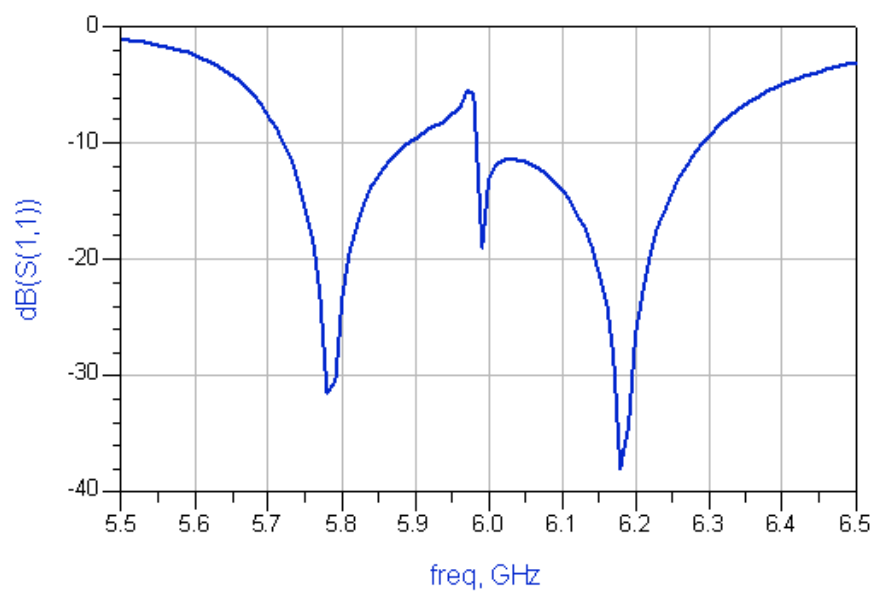

Figure11. Reflection co-efficient S11

The patch's radiation at the fringing fields results in a certain far field radiation pattern. This radiation pattern shows that the antenna radiates more power in a certain direction than another direction. The antenna is said to have certain directivity. The radiation pattern of this antenna at a frequency of $6.18 \mathrm{GHz}$ is shown in Fig.12. The polarization of the radiated field was linear.

Antenna gain describes how much power is transmitted in the direction of peak radiation to that of an isotropic source. The gain of this antenna with poly crystalline patch was $1.59 \mathrm{dBi}$ and directivity of $6.12 \mathrm{dBi}$ at $6.18 \mathrm{GHz}$.

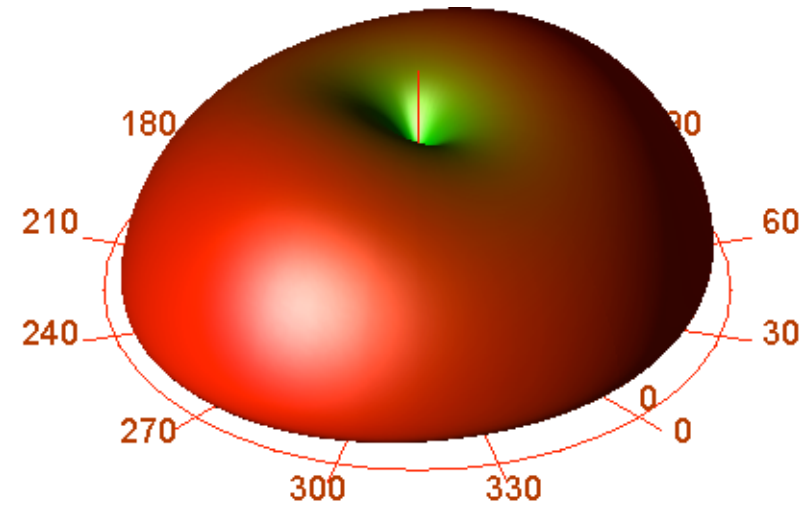

Figure12. Radiation pattern

The observation of the vertical radiation pattern also shows a good agreement between measurements and simulations.

The Equivalent circuit of the patch antenna is shown in Fig.13. The equivalent circuit is simulated and values are compared. The plot of S11 is shown in Fig.14. 


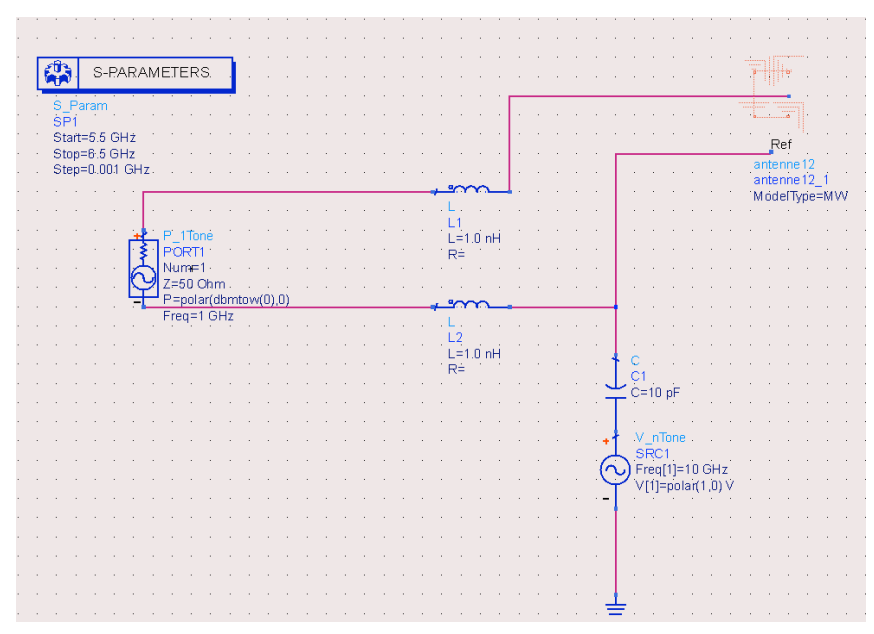

Figure 13: Equivalent circuit of patch antenna proposed

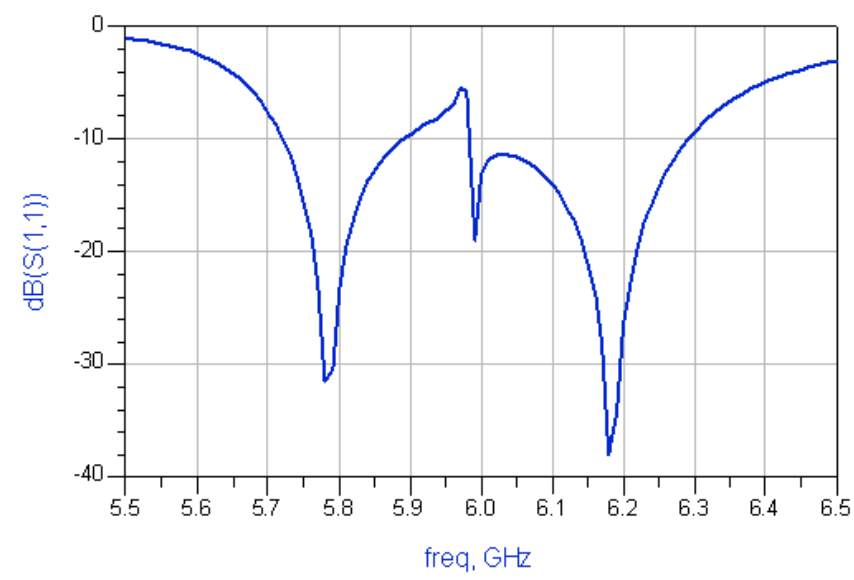

Figure 14: Reflection co-efficient S11 of equivalent circuit

The simulation of the reflection co-efficient S11 of equivalent circuit provides the same result of resonant frequency of the proposed patch antenna in Layout with a slight increase of return loss.

\section{Conclusions}

In this work, we presented a patch antenna with a collection grid of a photovoltaic solar cell dedicated to RF transmission. This work allowed us to evaluate the performance of a new type of patch antennas which are very advantageous and practical. Another advantage of this antenna is the large patch surface which is important for the largest possible energy output. This antenna is particularly well adapted for energy recovery and for the RF transmission with a dual large band.

The realization and design of this patch antenna based on collection grid of a Solar Cell and the measures of their different parameters as the parameter S11 reflection, gain, directivity and the radiated power will be studied in another work. The measurement results obtained will be compared with those of the simulations that we studied in this work.

\section{References}

[1] Okan Yurduseven, David Smith, Nicola Pearsall, Ian Forbes, "A solar cell stacked slot-loases suspended microstrip patch antenna with multiband resonance characteristics for WLAN and WIMAX SYSTEMS", Progress In Electromagnetics Research, Vol. 142, 321332, 2013

[2] Shynu, S. V., M. J. R. Ons, P. McEvoy, M. J. Ammann, S. J. McCormack, and B. Norton, "Integration of microstrip patch antenna with polycrystalline silicon solar cell," IEEE Trans. Antennas Propag, Vol. 57, No. 12, 3969-3972, Dec. 2009

[3] Turpin, T. W. and R. Baktur, "Meshed patch antennas integrated on solar cells," IEEE Antennas Wireless Propag. Lett, Vol. 8, 693-696, 2009.

[4] A. Suresh Kumar, S. Sundaravadivelu, 'Performance analysis of solar cell antenna with hybrid mesh and aght-8 material," Scholarly Journal of Scientific Research and Essay (SJSRE) Vol. 3(4), pp.51-55 May 2014

[5] Danesh, M. and J. R. Long, "An autonomous wireless sensor node incorporating a solar cell antenna for energy harvesting," IEEE Trans. Microw. Theory Tech, Vol. 59, No. 12, 3546-3555, Nov. 2011.

[6] Ons, M.J.R.; Shynu, S.V.; Ammann, M.J.; McCormack, S.; Norton, B. "Investigation on Proximity-Coupled Microstrip Integrated PV Antenna", IEEE Antennas and Propagation, 2007. EuCAP 2007, pp. 1 - 3.

[7] Bendel C., Henze N. and Kirchhof J. "Die photovoltaischePlanarantenne - High-Tec durch multifunktionale Nutzung der physikalischen Eigenschaften von Solarzellen," 16. Symposium photovoltaische Solarenergie, Staffelstein 2001, pp.3742

[8] Bendel C., Henze N. and Kirchhof J.: "Solar Planar Antenna - SOLPLANT," 17th European Photovoltaic Energy Conference, Munich 22-26 Oct. 2001.

[9] C. Boulord, «Développement de techniques de métallisation innovantes pour cellules photovoltaïques à haut rendement ", Thèse de Doctorat, INSA de Lyon, 2011.

[10] Y. G. Rabobason, G. P. Rigas, S. Swaisaenyakorn, B. Mirkhaydarov, B. Ravelo, M. Shkunov, P. R. Young and N. Benjelloun, "Design of flexible passive antenna array on Kapton substrate", Progress In Electromagnetics Research (PIER) C, Vol. 63, 2016, pp. 105-117.

[11] Y. G. Rabobason, G. P. Rigas, S. Swaisaenyakorn, B. Mirkhaydarov, B. Ravelo, M. Shkunov, P. R. Young and N. Benjelloun, "Design and synthesis of flexible switching 1x2 antenna array on Kapton substrate”, Eur. Phys. J. Appl. Phys. (EPJAP), Vol. 74, No. 3 (30102), June 2016, pp. 1-10

[12] T.Bendib, F. Djeffal, "Electrical Performance Optimization of Nanoscale Double-Gate MOSFETs Using Multi-objective Genetic Algorithms," IEEE 
Trans on Electron Devices, Vol. 58, pp. $3743-3750$, 2011.

[13]F. Djeffal, N. Lakhdar, A. Yousfi, "An optimized design of 10-nmscale dual-material surrounded gate MOSFETs for digital circuit applications," Physica E: Low-dimensional Systems and Nanostructures, Vol. 44, pp. 339-344, 2011.

[14]A. Cheknane, B. Benyoucef, J.P. Charles and R. Zerdoum, "Optimisation et Conception d'une Grille Collectrice Appliquée aux Photopiles Fonctionnant sous Haute Concentration Solaire," Rev. Energ. Ren. Vol. 7 (2004) 95-108.

[15]A. Cheknane, B. Benyoucef, J.-P. Charlesb, R. Zerdoumc, M. Trarid, "Minimization of the effect of the collecting grid in solar cell based silicon," Solar Energy Materials and Solar Cells 87 (2005) 557-565

[16]P. Morvillo, E. Bobeico, F. Formisano, F. Roca, "Influence of metal grid patterns on the performance of silicon solar cells at different illumination levels," Materials Science and Engineering B 159-160 (2009) 318-321

[17]M.A. Green, Solar Cells: Operating Principles Technology and System Applications, University of New South Wales, Sydney, 1995.

[18] A. Morales-Acevedo, "Optimum concentration factor for silicon solar cells," Solar Cells 14 (1985) 43-49

[19] L. Wen, L. Yueqiang, C. Jianjun, C. Yanling, W. Xiaodong, Y. Fuhua, "Optimization of grid design for solar cells," Journal of Semiconductors 31 (2010) 014006.1-014006.6

[20]C. Baccouch, D. Bouchouicha, H. Sakli and T. Aguili, "Optimization of the Collecting Grid Front Side of a Photovoltaic Cell Dedicated to the RF Transmission", 2nd International Conference on Automation, Control, Engineering and Computer Science ACECS, 22- 24 March 2015 - Sousse, Tunisia. 